\title{
Kualitas Organoleptik Daging Sapi Asap dengan Memanfaatkan Ampas Gilingan Kopi Sebagai Bahan Bakaran
}

\author{
I Made Purwa Dana Atmaja* \\ Program Studi Manajemen Tata Boga, Sekolah Tinggi Pariwisata Nusa Dua Bali
}

\section{A R T I C L E I N F O}

Article history:

Received 19 May 2018

Received in revised form 13 June 2018

Accepted 28 July 2018

Available online 26 August 2018

\section{Kata Kunci:}

Pengasapan, Ampas

gilingan kopi, organoleptik.

Keywords:

Smoked, coffee mill waste, organoleptic

\section{A B S T R A K}

Penelitian ini bertujuan untuk mengetahui kualitas organoleptik daging sapi asap dengan memanfaatkan ampas gilingan kopi sebagai bahan bakaran. Daging sapi diolah dengan menggunakan metode pengasapan menggunakan ampas gilingan kopi sebagai bahan bakaran selanjutnya hasil olahan daging sapi asap diuji oleh 20 orang panelis terlatih yang merupakan dosen dan mahasiswa jurusan Tata Boga secara organoleptik. Hasil olahan daging sapi asap diuji oleh panelis dengan bantuan panca indera (sensory evaluation) yaitu dengan mengecap rasa, mencium aroma, melihat warna dan merasakan tekstur dari selai. Hasil pengamatan dari panelis diberikan skor dengan menggunakan skala likert sehingga ditemukan katagori kualitas daging sapi asap yang dihasilkan. Penelitian ini dilakukan di dapur praktek Sekolah Tinggi Pariwisata Nusa Dua Bali. Teknik pengumpulan data penelitian ini yaitu dengan cara eksperimen dan dokumentasi. Teknik analisis yang digunakan adalah deskriptif kualitatif dengan uji organoleptik. Berdasarkan hasil penelitian dapat disimpulkan: 1) Hasil eksperimen daging sapi asap dengan memanfaatkan ampas gilingan kopi setelah dihitung dengan menggunakan skala likert memiliki kualitas yang baik dengan nilai rata-rata $70,5 \%, 2$ ) ditinjau dari aspek penilaian uji organoleptik dari segi warna menghasilkan warna merah muda kecoklatan dalam katagori baik, 3) aroma yang dihasilkan khas dagng sapi dengan campuran aroma kopi, 4) tekstur daging sapi lembut dengan katagori sangat baik, 5) rasa daging sapi asap sangat khas perpaduan dengan aroma kopi.

\section{A B S T R A C T}

This study aims to determine the organoleptic quality of smoked beef by utilizing coffee mill pulp as a fuel. Beef was processed using the method of fumigation using coffee mill pulp as the next burnt material processed by smoked beef tested by 20 trained panelists who were organoleptic lecturers and students majoring in Cooking. Processed smoked beef is tested by panelists with the help of the senses (sensory evaluation), namely by tasting the taste, smell the aroma, see the color and feel the texture of the jam. The observations from the panelists were given a score using the Likert scale so that the categories of quality of smoked beef were produced.This research was conducted in the practical kitchen of the Nusa Dua Tourism College in Bali. The data collection technique of this research is by experimentation and documentation. The analysis technique used was descriptive qualitative with organoleptic tests. Based on the results of the study it can be concluded: 1) The experimental results of smoked beef using coffee mill pulp after it was calculated using the Likert scale have good quality with an average value of $70.5 \%$,2) seen from the aspect of organoleptic test assessment in terms of color yield brownish pink in good category, 3) the aroma produced is typical of beef with a mixture of aroma of coffee, 4) texture of tender beef with very good category, 5) the taste of smoked beef is very typical blend with the aroma of coffee.

Copyright (C) Universitas Pendidikan Ganesha. All rights reserved.

\footnotetext{
* Corresponding author.

E-mail addresses: purwadanaatmajaa@gmail.com (I Made Purwa Dana Atmaja)
} 


\section{Pendahuluan}

Salah satu limbah organik yang banyak di pulau Bali adalah ampas kopi karena banyaknya wisatawan dan masyarakat yang memang menyukai minuman kopi. Ampas kopi merupakan limbah industri pangan yang dihasilkan dari pengolahan biji kopi. Dari 0,50 kg bubuk kopi yang siap digunakan menghasilkan setidaknya 0,34 kg ampas kopi. Sebagaimana halnya limbah industri pangan yang lain, maka limbah ampas kopi juga mempunyai potensi untuk dimanfaatkan untuk mengurangi pencemaran lingkungan. Limbah Industri pangan dapat menimbulkan masalah dalam penanganannya, karena mengandung karbohidrat, protein , lemak, garam-garam mineral dan juga sisa-sisa bahan kimia yang dipergunakan dalam proses pengolahan dan pembersihan. Limbah yang semakin banyak dan menumpuk akan berbau dan menjadi sumber berkembangnya mikroba yang pada akhirnya juga akan menimbulkan berbagai macam penyakit, sehingga limbah industri pangan perlu penanganan yang baik.

Daging merupakan bahan makanan hewani yang digemari oleh seluruh lapisan masyarakat karena rasanya yang lezat dan mengandung nilai gizi yang tinggi. Daging adalah salah satu hasil ternak yang hampir tidak dapat dipisahkan dari kehidupan manusia. Daging dapat menimbulkan kepuasan atau kenikmatan bagi yang memakannya karena kandungan gizinya yang lengkap sehingga keseimbangan gizi untuk hidup dapat terpenuhi. Soeparno (2009) mendefinisikan daging sebagai semua jaringan hewan dan semua produk hasil pengolahan jaringan tersebut yang sesuai untuk dimakan serta tidak menimbulkan gangguan kesehatan bagi yang memakannya. Daging sapi merupakan produk pangan asal hewan yang bersifat mudah rusak (perishable) dan merupakan media untuk berkembangnya mikroba, yang diakibatkan karena kandungan gizinya yang lengkap dan sangat digemari oleh mikroorganisme baik pathogen (menyebabkan sakit) maupun pembusuk. Menurut Sutaryo (2004) daging sapi sangat mudah mengalami kerusakan disebabkan adanya aktivitas mikroorganisme perusak sehingga diperlukan penanganan, penyimpanan, ataupun pengolahan yang sesuai. Aktivitas mikroorganisme ini dapat mengakibatkan perubahan fisik maupun kimiawi yang tidak diinginkan, sehingga daging tersebut rusak dan tidak layak untuk dikonsumsi. Oleh karena itu, perlu adanya penanganan lebih lanjut untuk mencegah adanya aktivitas mikroorganisme di dalam daging, sehingga dapat menjaga dan meningkatkan kualitas dan mutu daging tersebut. Salah satu cara penanganan daging adalah dengan pengolahan daging segar menjadi daging asap (smoking).

Metode pengolahan daging segar dengan pengasapan adalah salah satu teknik pengawetan tertua yang dikenal manusia. Walaupun saat ini sudah banyak metode pengawetan moden, teknik pengasapan masih dipakai di banyak tempat. Seiring perkembangan zaman, metode pengasapan juga dimodifikasi sesuai kebutuhan manusia. Inti dari metode pengasapan adalah meniupkan asap pada daging sehingga daging menjadi tahan lama \& memiliki rasa serta aroma yang khas. Jika menelusuri sejarahnya, teknik pengasapan diperkirakan sudah dilakukan oleh orang-orang Inggris \& daratan Eropa sejak Abad Pertengahan (sekitar abad ke-5) pada bahan-bahan makanan seperti daging \& ikan mentah. Khusus untuk ikan, ikan yang banyak diasapkan di kawasan Eropa adalah ikan hering \& kod asin (salt cod). Tujuan utama dari pengasapan pada masa itu adalah agar daging atau ikan tahan lama dalam perjalanan jauh sehingga bisa dikirim ke wilayah-wilayah lain di Eropa, Timur Tengah, bahkan India. Kemungkinan besar itulah penyebab utama mengapa metode pengasapan bisa begitu populer di berbagai belahan dunia. Teknik pengasapan kembali populer dengan ditemukannya metode pengasapan baru yang mirip dengan metode pengasapan sekarang. Bila tujuan utama dari metode pengasapan yang lama adalah untuk membuat daging atau ikan lebih tahan lama, metode pengasapan yang baru bertujuan untuk memberi rasa serta aroma yang khas pada daging atau ikan. Metode pengasapan modern secara umum sama dengan metode pengasapan tradisional, namun memakai peralatan yang canggih \& langkah-langkah yang lebih terkontrol.

Pengasapan daging sapi dengan metode pengasapan panas dapat menggunakan bahan bakaran berupa batok kelapa, kayu dan serbuk kayu. Pada umumnya kayu kopi yang digunakan sebagai bahan bakaran dalam metode pengasapan. Namun selain harganya yang cukup mahal, dengan menggunakan bahan bakaran demikian akan hanya membuat daging lebih awet dan memiliki aroma asap. Perlu adanya bahan alternatife lain untuk bahan bakaran pengasapan untuk meningkatkan kualitas daging sapi itu sendiri baik dari aspek rasa, aroma, tekstur dan juga warna. Disini peneliti mencoba untuk menggunakan ampas kopi sebagai bahan bakaran untuk pengasapan karena ampas kopi yang mudah didapatkan dan merupakan suatu limbah yang dapat mencemari lingkungan.

Berdasarkan latar belakang, identifikasi masalah dan rumusan masalah di atas, dapat ditentukan yang menjadi tujuan penelitian adalah untuk mendeskripsikan kualitas daging sapi asap ditinjau dari aspek warna, rasa, terkstur dan aroma dengan metode pengasapan (Smoking) yang menggunakan ampas biji kopi sebagai bahan bakaran dalam metode pengasapan. 


\section{Metode}

Metode penelitian yang digunakan adalah metode penelitian kualitatif. Dalam proses penelitian ini data kualitatif berupa uraian hasil kuesioner dari panelis mengenai kualitas dari daging sapi asap dengan menggunakan ampas biji kopi dalam proses memasaknya (Sugiyono, 2013). Objek penelitian ini adalah ampas biji kopi jenis arabika yang telah melalui proses ekstraksi dengan mesin espresso yang sudah melalui proses roasting dan telah di haluskan dengan mesin grinder. Subjek penelitian dalam penelitian ini adalah penulis sendiri yang melaksanakan eksperimen dan sebagai salah satu sumber data primer mengenai cara pembuatan daging sapi asap dengan ampas biji kopi tersebut. Penelitian dilaksanakan di dapur praktek STP Nusa Dua Bali yang beralamat di jl.darmawangsa, Kampial, Kuta Selatan.

Data diperoleh dari uji organoleptic (Saragih, 2015), dokumentasi, dan studi pustaka (Sugiyono, 2013) untuk memahami hasil eksperimen. Eksperimen yang dilakukan yaitu membuat daging sapi asap dengan ampas biji kopi sebagai bahan bakaran sesuai dengan resep baku (Chris Lilly, 2009). Bahan yang digunakan ditunjukkan pada Tabel 1.

Tabel 1. Resep Daging Sapi Asap Dengan Ampas Biji Kopi Sebagai Bahan Bakaran

\begin{tabular}{clcc}
\hline No. & \multicolumn{1}{r}{ Nama Bahan } & Kuantiti & Unit \\
\hline 1 & Sandung lamur atau & 500 & $\mathrm{Gr}$ \\
& brisket & & \\
2 & Garam & 50 & $\mathrm{Gr}$ \\
3 & Gula & 25 & $\mathrm{Gr}$ \\
4 & Onion Powder & 25 & $\mathrm{Gr}$ \\
5 & Lada Hitam & 25 & $\mathrm{Gr}$ \\
6 & Ampas biji Kopi & 1000 & $\mathrm{Gr}$ \\
7 & Garlic Powder & 25 & $\mathrm{Gr}$ \\
8 & Coriander Powder & 25 & $\mathrm{Gr}$ \\
9 & Worchester Sauce & 30 & $\mathrm{Ml}$ \\
10 & Paprika Powder & 25 & $\mathrm{Gr}$ \\
11 & Dried Oregano & 25 & $\mathrm{Gr}$ \\
\hline
\end{tabular}

Uji organoleptic dilakukan oleh beberapa panelis dengan mengisi kuesioner menggunakan skala likert untuk memperoleh data kualitas daging sapi. Panelis terlatih sebanyak 20 orang yaitu mahasiswa semester enam Jurusan Manajemen Tata Boga di lingkungan Sekolah Tinggi Pariwisata Nusa Dua Bali. Pengamatan secara uji organoleptik bertujuan untuk mendapatkan kualitas terhadap warna, aroma, tekstur,keempukan dan rasa Daging Sapi Asap Dengan Ampas Biji Kopi sebagai bahan bakaran. Saragih (2015) menyatakan uji organoleptik adalah pengujian bahan secara subyektif dengan pertolongan panca indera manusia. Pada umumnya uji organoleptik disebut juga pengujian secara sensory evaluation, yaitu pengujian yang didasarkan atas indera penglihatan, indera peraba, indera penciuman dan indera perasa. Dokumentasi yang diambil dalam penelitian ini adalah foto-foto atau gambar mengenai alat yang digunakan dalam penelitian ini, bahan yang digunakan, proses penelitian, serta hasil akhir dari daging sapi asap ampas biji kopi dengan bantuan kamera. Studi pustaka yang dilakukan yaitu studi pustaka dari dokumen-dokumen yang ada pada berbagai sumber untuk menggali aspek metode pengolahan daging sapi asap yang dipergunakan sebagai sample dalam penelitian ini. Teknik analisis data yang digunakan dalam penulisan ini adalah teknik analisis deskriptif kualitatif yaitu data reduction, data display, dan conclusion drawing/verification (Sugiyono, 2013).

\section{Hasil dan pembahasan}

Eksperimen pembuatan daging sapi asap dengan ampas kopi sebagai bahan bakaran dilakukan sebanyak tiga kali pengulangan untuk memperoleh data yang reliable. Berikut adalah deskripsi data yang dihasilakan selama tiga kali tahap percobaan eksperimen. eksperimen dengan hasil yang paling bagus ditunjukkan pada Gambar 1. 

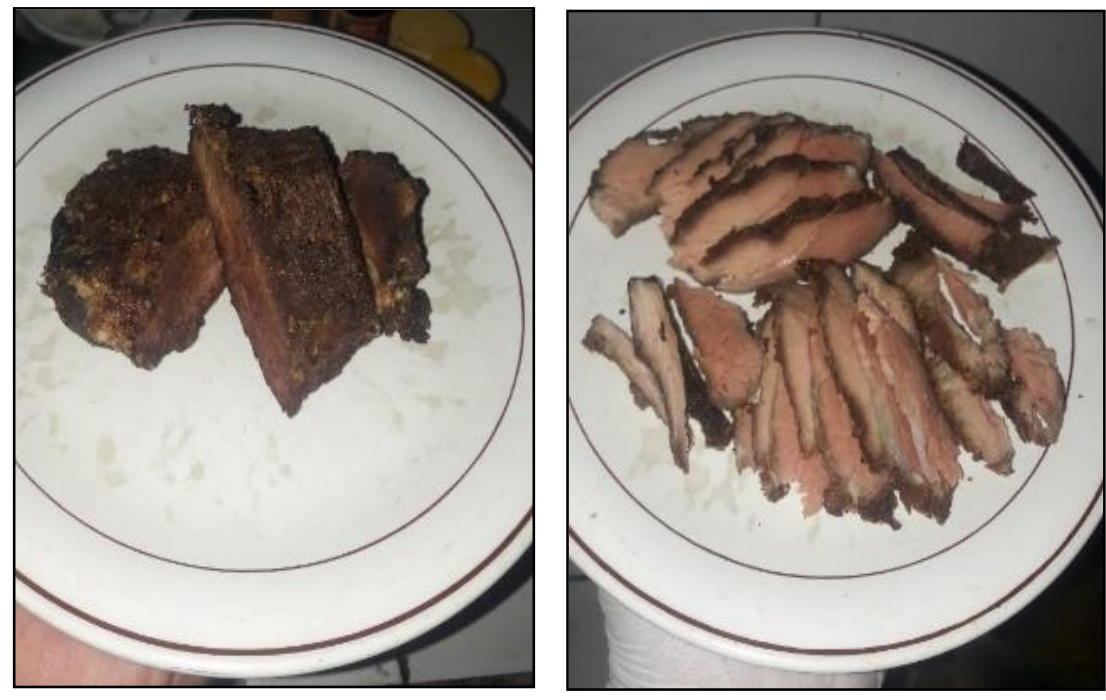

Gambar 1 Hasil Eksperimen Daging Sapi Asap dengan ampas biji kopi

Hasil uji organoleptik bertujuan untuk mendapatkan kualitas terhadap warna, aroma, tekstur,keempukan dan rasa Daging Sapi Asap Dengan Ampas Biji Kopi sebagai bahan bakaran. Hasil uji organoleptik diukur menggunakan metode Skala Likert guna mendapatkan hasil skor akhir variabel yang diukur. Rekapitulasi nilai indeks Skala Likert ditunjukkan pada Tabel 2.

Tabel 2. Rekapitulasi Nilai Indeks Variabel Pada Daging Sapi Asap Dengan Ampas Kopi Sebagai Bahan Bakaran

\begin{tabular}{llll}
\hline No & Aspek Penilaian & Nilai Index (\%) & Kriteria Interpretasi \\
\hline 1 & Warna & 51 & Cukup Baik \\
2 & Aroma & 85 & Sangat Baik \\
4 & Rasa & 84 & Sangat Baik \\
5 & Tekstur & 62 & Baik \\
\multicolumn{2}{l}{ Rata-Rata Total } & 70.5 & Baik \\
\hline
\end{tabular}

Keterangan:

Nilai Index $=$ Total Skor Pada Setiap Variabel $/$ Skor Tertinggi (Y) X 100\%

Berdasarkan Tabel 2 hasil uji organoleptik yang dilakukan oleh 20 orang panelis, data yang didapat dari segi warna untuk daging sapi asap dengan ampas kopi sebagai bahan bakaran adalah 2 dari 20 orang panelis atau10\% menyatakan Merah Cerah, 8 dari 20 orang panelis $40 \%$ menyatakan cukup merah cerah, 9 dari 20 orang panelis $45 \%$ menyatakan kurang merah cerah dan 1 dari 20 orang panelis $5 \%$ menyatakan sangat kurang merah cerah dan pucat. Aroma untuk daging sapi asap dengan ampas kopi sebagai bahan bakaran adalah 8 dari 20 orang panelis atau $40 \%$ menyatakan aroma sangat beraroma khas daging dengan aroma asap ampas kopi, 10 dari 20 orang panelis atau 50\% menyatakan beraroma khas daging dengan aroma asap ampas kopi, 1 dari 20 orang panelis atau 5\% menyatakan aroma cukup beraroma khas daging dengan aroma asap ampas kopi, dan 1 dari 20 orang panelis atau 5\% menyatakan aroma kurang khas daging dengan aroma asap ampas kopi. Rasa untuk daging sapi asap dengan ampas kopi sebagai bahan bakaran adalah 6 dari 20 orang panelis atau 30\% menyatakan rasa sangat gurih, 12 dari 20 orang panelis atau $60 \%$ menyatakan rasa gurih, dan 2 dari 20 orang panelis atau $10 \%$ menyatakan rasa cukup gurih. Tekstur untuk daging sapi asap dengan ampas kopi sebagai bahan bakaran adalah 6 dari 20 orang panelis atau $30 \%$ menyatakan tekstur mudah putus dan mudah dikunyah, 10 dari 20 orang panelis atau 50\% menyatakan tekstur cukup mudah putus dan mudah dikunyah dan 4 dari 20 orang panelis atau $20 \%$ menyatakan tekstur kurang mudah putus dan kurang mudah dikunyah.

Warna dari daging sapi asap merah agak kecokelatan. Saat daging sapi di marinade warnanya stabil. Hal ini disebabkan adanya garam dan gula pasir yang menyebabkan warna daging sapi menjadi merah cerah. Merah kehitaman dari daging sapi tersebut dikarenakan daging sapi yang tadinya merah cerah dipengaruhi asap yang mengandung karbon berwarna hitam sehingga mempengaruhi warna daging 
sapi tersebut. Penampakan umum dari daging sapi asap agak kurang menarik jika ditinjau dari indera penglihatan karena warna cokelat kehitaman dari bagian luar produk tersebut. Penampilan umum daging sapi asap dipengaruhi oleh proses marinade dan pengasapan. Setelah dimarinade warna daging merah cerah tetapi setelah diasap berubah menjadi merah muda kecokelatan.

Aroma dari daging sapi asap dengan menggunakan ampas biji kopi sebagai bahan bakaran yaitu perpaduan bau asap dengan bau kopi dan aroma khas daging sapi. Aroma daging sapi asap dengan ampas kopi sebagai bahan bakaran merangsang penciuman sehingga membuat seseorang tertarik untuk mencicipinya. Bau atau aroma dipengaruhi oleh proses marinade dengan penambahan garam, gula pasir dan bumbu kering. Selain itu bau atau aroma juga dipengaruhi oleh senyawa fenol dan komponen asap yang dihasilkan oleh ampas kopi. Menurut Cruz et.al (2012), ampas kopi mengandung 1,2\% Nitrogen, 0,02\% Fosfor, dan 0,35\% Kalium. Ampas kopi mengandung 2,28\% nitrogen, fosfor 0,06\% dan 0,6 kalium. pH ampas kopi sedikit asam, berkisar 6,2 pada skala pH. Selain itu, ampas kopi mengandung magnesium, sulfur, dan kalsium (Losito, 2011). Pembakaran ampas biji kopi menghasilkan aroma khas kopi dengan yang wangi dan adiktif.

Rasa daging sapi asap dirasakan oleh indera perasa yaitu rasa gurih daging sapi dipengaruhi oleh proses curing dimana ditambah dengan garam dapur dan gula pasir. Peranan gula pasir pada proses curing bertujuan untuk menetralkan rasa asin yang ditimbulkan oleh garam menghasilkan rasa yang gurih. $\mathrm{pH}$ ampas kopi sedikit asam, berkisar 6,2 pada skala pH. Selain itu, ampas kopi mengandung magnesium, sulfur, dan kalsium (Losito, 2011). Asap ampas kopi pada rasa daging memberikan rasa segar dipermukaan daging sapi asap.

Tekstur daging sapi asap sudah cukup empuk. Hal ini dikarenakan proses curing pada daging sapi yang dilakukan cukup lama. Semakin lama proses curing maka semakin tinggi tingkat keempukan. Selain itu daging alot juga disebabkan kurang masak akibat kurang lama diasap.

Senyawa kimia utama yang terdapat di dalam asap antara lain asam formiat, asetat, butirat, kaprilat, vanilat dan asam siringat, dimetoksifenol, metal glioksal, furfural, methanol, etanol, oktanol, asetaldehid, diasetil, aseton, dan 3,4- benzinpiren (Lawrie, 1995). Daging segar mempunyai pH pada kisaran pH normal, yaitu 5,4 sampai 5,9 (Snyder dan Orr, 1964 dalam Soeparno, 1998), sehingga mudah busuk karena merupakan $\mathrm{pH}$ yang ideal bagi pertumbuhan dan perkembang biakan bakteri. Pemanasan akan menyebabkan peningkatan $\mathrm{pH}$ daging (Cross dan Overby, 1988), namun dapat juga menurunkan $\mathrm{pH}$, karena komponen asap yang melekat pada daging mempunyai sifat asam, diantaranya asam karboksilat yang meliputi asam format, asetat, dan butirat (Winarno et al, 1980). Senyawa yang terdapat di dalam asap, yaitu alkohol-alkohol aliphatik, aldehida, keton, dan asam organik termasuk furfural, formaldehida, asam-asam dan fenol yang memiliki daya bakterostatik atau bakterisidal. Bagian ligninnya akan pecah menjadi senyawa fenol, quinol, quaicol dan pyrogalol yang merupakan bagian dari jenisjenis senyawa antioksidan dan antiseptik (Moelyanto, 1982)

\section{Simpulan dan saran}

Berdasarkan pada uraian atau pembahasan pada bab III, dapat disimpulkan bahwa: (1) Ditinjau dari hasil analisis data yang diperoleh dari uji panelis, ampas biji kopi dapat digunakan sebagai bahan bakaran dalam pembuatan daging sapi asap, dimana dari hasil eksperimen dan uji panelis yang dilakukan daging sapi asap dengan menggunakan ampas kopi sebagai bahan bakaran memiliki aroma dan rasa yang lebih khas dari daging dengan pengasapan menggunakan serbuk kayu, kayu atau batok kelapa pada umumnya yaitu perpaduan rasa serta aroma dari ampas kopi, daging dan bumbu kering; (2) Hasil eksperimen daging sapi asap dengan memanfaatkan ampas gilingan kopi setelah dihitung dengan menggunakan skala likert memiliki kualitas yang baik dengan nilai rata-rata $70,5 \%$ ditinjau dari aspek penilaian uji organoleptik warna, aroma, tekstur, rasa dan Warna dari daging sapi asap dengan ampas kopi sebagai bahan bakaran berwarna merah agak kecokelatan karena setelah dimarinade warna daging merah cerah tetapi setelah diasap berubah menjadi merah muda kecokelatan, aroma yang dihasilkan dari daging sapi asap dengan ampas kopi sebagai bahan bakaran perpaduan bau asap dengan bau kopi dan aroma khas daging sapi, tekstur yang dihasilkan tekstur cukup mudah putus dan mudah dikunyah dan rasa yang dihasilkan gurih dari garam dapur dan gula pasir.

Berdasarkan peneltian dan simpulan di atas, maka penulis memberikan beberapa saran yaitu: (1) Kiranya penelitian berikutnya dapat memberikan solusi pada warna daging sapi asap agar memliki warna yang lebih memberikan daya tarik kepada konsumen, karena dalam penelitian ini setelah daging sapi melalui proses pengasapan warna daging yang semula merah cerah berubah menjadi cokelat kehitaman pada bagian luar dan merah muda pada bagian dalam, hal ini akan mempengaruhi minat konsumen atau masyarakat untuk mengkonsumsi produk olahan daging sapi asap; (2) Perlu adanya penelitian kedepan, 
mengenai kandungan zat nutrisi pada daging sapi asap dengan menggunakan ampas biji kopi sebagai bahan bakaran dapat diuji secara laboratorium

\section{Daftar Rujukan}

Davids, K. 1996. Home Coffe Roasting. New York: St. Martin's Griffin

Direktorat Jenderal Perkebunan Departemen Pertanian. 2011. Buku Kopi. Jakarta.

Panggabean,Edy. 2011. Buku Pintar Kopi. Jakarta Selatann : PT Agro Media Pustaka.

Rahardjo, P. 2012. Panduan Budidaya dan Pengolahan Kopi Arabika dan Robusta. Jakarta: Penebar Swadaya.

Ciptadi, W. dan Nasution, M.Z. 1985. Pengolahan Kopi. Bogor: Fakultas Teknologi Institut Pertanian Bogor.

Clarke, R. J. and Macrae, R. 1987. Coffe chemestry (Volume 1). Elsevier AppliedScience, London and New York.

Clarke, R. J. and Macrae, R. 1987. Coffe Technology (Volume 2). Elsevier Applied Science, London and New York.

Najiyati, S. dan Danarti. 2001. Kopi Budidaya dan penanganan Lepas Panen. Jakarta : Penebar Swadaya.

Siswoputranto, P .S. 1993. Kopi Internasional dan Indonesia. Jakarta: Kanasius.

Spillane. J. J. 1990. Komoditi Kopi Peranannya Dalam perekonomian Indonesia. Jakarta: Kanasius.

Najiyati S dan Danarti. 1997. Budidaya Kopi dan Pengolahan Pasca Panen. Jakarta: Penebar Swadaya.

Panggabean, Edy. 2011. Mengeruk Untung dari Bisnis Kopi Luwak. Jakarta: Agromedia Pustaka.

Ria, J.H., dan Djumidi. 2000. Inventaris Tanaman Obat Indonesia (I) Jilid 1. Jakarta: Departemen Kesehatan dan Kesejahteraan Sosial Republik Indonesia Badan Penelitian dan Pengembangan Kesehatan.

Haryono, B dan Kurniati, D. 2013. Seri Tanaman Baku Industri Kopi. Jakarta: Trisula Adisakti.

Bahar,Burhan. 2003. Panduan Praktis Memilih Produk Daging Sapi. Jakarta: PT. Gramedia Pustaka Utama.

Buckle KA, Edward RA,Fleet GH, Wooton M. 1987. Ilmu Pangan. Penerjemah. Jakarta: UI Press. Terjemahan dari : Food Science.

Maruddin. Fatma. 2004. Kualitas Daging Sapi Asap Pada Lama Pengasapan Penyimpanan. J. Sains \& Teknologi,Agustus, Vol.4 No.2:83-90.

Soeparno. 1994. Ilmu dan Teknologi Daging., Yogyakarta: Gajah Mada University Press.

Sugitha I Made. 1995. Teknologi Hasil Ternak. Padang: Universitas Andalas.

Mochanto, S.Et al. 1997. Pengelolaan Makanan. Bandung: Angkasa Bandung.

Nuri. 2008. Pengolahan Makanan Dengan Pengasapan.

Varnam, H.A. and Sutherland, J. P. 1994. Beverages (Technology, Chemestry and Microbiology). London: Chapman and Hall.

Girard JP. 1992. Smoking, In: Technology of Meat and Meat Product, J.P. Girard (ed.), New York: Ellis Horwood. 
Hamm R. 1977. Analysis of Smoke and Smoked Foods. Pure Appl Chem 49: 1655- 1666.

Lawrie RA. 1995. Ilmu Daging. Jakarta: Penerbit Universitas Indonesia.

Lilly, Chris. 2009. Big Bob Gibson's BBQ Book. New York : Clarkson Potter.

Sugiyono. 2013. Metode Penelitian Kuantitatif Kualitatif dan R\&D. Bandung: Alfebeta.

Sukardi. 2011. Metodologi Penelitian Pendidikan Kompetensi dan Praktiknya. Jakarta : PT. Bumi Aksara 